IRA-International Journal of Management \&

Social Sciences

ISSN 2455-2267; Vol.16, Issue 02 (April-June 2020)

Pg. no. 45-58.

Institute of Research Advances

http://research-advances.org/index.php/RAJMSS

\title{
Environmental Informatics and Educational Opportunities in Post Graduate level-Indian Potentialities based on International Scenario
}

\author{
P. K. Paul ${ }^{1 \#}$ P. S. Aithal ${ }^{2} \&$ A. Bhuimali ${ }^{3}$ \\ ${ }^{1}$ Executive Director, MCIS, Department of CIS, Information Scientist (Offg.), Raiganj University, \\ India-733 134 \\ ${ }^{2}$ Vice Chancellor, Srinivas University, Karnataka, India \\ ${ }^{3}$ Vice Chancellor, Raiganj University (RGU), West Bengal, India
}

\# corresponding author

Type of Work: Peer Reviewed.

DOl: http://dx.doi.org/10.21013/jmss.v16.n2.p2

\section{How to cite this paper:}

Paul, P.K., Aithal, P.S., Bhuimali, A. (2020). Environmental Informatics and Educational Opportunities in Post Graduate level-Indian Potentialities based on International Scenario. IRAInternational Journal of Management \& Social Sciences (ISSN 2455-2267), 16(2), 45-58. doi:http://dx.doi.org/10.21013/jmss.v16.n2.p2

(C) Institute of Research Advances.

\section{(cc) EY-NC}

This work is licensed under a Creative Commons Attribution-Non Commercial 4.0 International License subject to a proper citation to the publication source of the work.

Disclaimer: The scholarly papers as reviewed and published by the Institute of Research Advances (IRA) are the views and opinions of their respective authors and are not the views or opinions of the IRA. The IRA disclaims of any harm or loss caused due to the published content to any party.

Institute of Research Advances is an institutional publisher member of Publishers International Linking Association Inc. (PILA-CrossRef), USA. The institute is an institutional signatory to the Budapest Open Access Initiative, Hungary advocating the open-access of scientific and scholarly knowledge. The Institute is a registered content provider under Open Access Initiative Protocol for Metadata Harvesting (OAl-PMH).

The journal is indexed \& included in WorldCat Discovery Service (USA), CrossRef Metadata Search (USA), WorldCat (USA), OCLC (USA), Open J-Gate (India), EZB (Germany) Scilit (Switzerland), Airiti (China), Bielefeld Academic Search Engine (BASE) of Bielefeld University, Germany, PKP Index of Simon Fraser University, Canada. 


\begin{abstract}
The academic sector is changing rapidly and different components have been added in the academic components. The education systems including academic bodies, programs, educational institutes change different aspects in the recent past. The interdisciplinary sciences are booming internationally. Among the interdisciplinary subjects, Environmental Sciences is an important one. On the other hand, Information Science is also truly interdisciplinary. This Information Science is also called as Informatics. The fusion or combination of these two subjects led the new academic body called 'Environmental Informatics'. Environmental Informatics is very close with exiting field Geo-Informatics and thus it is also called as an extension of Geo-Informatics. Environmental Informatics is the solution to different environmental affairs, issues, problems, etc. Internationally, many universities have started academic programs on Environmental Informatics leading to Certificate, Diploma, Bachelors, Masters, MPhil, PhD in the subject. The present paper is an overview of Environmental Informatics including its features, functions, stakeholders emphasizing the availability of Post Graduate Programs in the field. Paper highlighted the course contents, job prospects, carrier opportunities in brief. Paper also proposed the possible programs at Masters levels; which can be a good solution both for abroad and the Indian education system.
\end{abstract}

Keywords: Environmental Informatics, Information Science, Informatics, Environment, Environmental Science, India, Higher Education

\title{
Introduction
}

Environmental Informatics is the emerging practicing domain and applications of Information Technology and Computing applications in Environment, Nature and Ecology also partially related areas like Geology, Agriculture, Forestry, Geography, Climatology, Oceanography, etc. Environmental Informatics also called as Eco Informatics and Ecology Informatics in some contexts. Environmental Informatics is broader than Environmental Information Technology and may also deal with manual information management related to environment and ecology. Environmental Informatics deals with completely natural processes with language common to both humans and computers [1], [5], 911]. Different emerging technologies are applicable in different sectors allied areas of the studies related to the environment (but not limited to) following-

- Environmental Science

- Environmental Studies

- Environmental Management

- Environmental Engineering etc.

\section{Objective}

The present paper is conceptual and reviews based and intends with the following aim and objective-

- To gain knowledge on Informatics and overview of Environment and related areas including the components of the Environmental Sciences.

- To learn about the features, characteristics, stakeholders of the Environmental Informatics including its evolution.

- To get the job scenario and carrier opportunities in Environmental Informatics in different sectors.

- To find out the similar branches related to the Environmental Informatics at a glance.

- To learn about the educational programs on Environmental Informatics and allied areas in different international universities using the proposed methods.

- To learn the potentialities of offering a Masters degree in Environmental Informatics with possible nomenclature.

- To get the possibilities of research-based Environmental Informatics programs at the Masters level. 


\section{Methods}

This paper is theoretical as well as educational in nature. For thus different secondary sources are used to learn about the Environmental Informatics and allied fields. Various primary sources such as journals are used to get the current scenario of Environmental Informatics. Web review is undertaken to get the universities offering Environmental Informatics programs; and here search strategy used title and keywords are used 'Degrees on Environmental Informatics', 'MSc Environmental Informatics', 'Academic Programs on Environmental Informatics'. Further, the result considered up to 20 pages (if available). Then the analysis is incorporated in this paper.

\section{Environmental Informatics: Overview with Features and Stakeholders}

Environmental Informatics is the applications, design, development of IT and Computing for the environmental and ecological areas viz. ecological analysis, synthesis, including forecasting and management. Environmental Informatics is applicable in different areas of the natural systems and environment including the river systems, lakes, marine systems, forestry, disaster management agriculture, etc [2], [3], [12]. Information technology components and Computer Science components viz. AI \& ES, artificial neural networks, genetic algorithms, fuzzy logic are also important in Environmental Informatics practice. Moreover, in the conservation of biodiversity and fishery management also it is important. The branch is very close to the Computational Ecology, Environmental Data Sciences as well. The following are the core features of the Environmental Informatics-

- It is a field of interdisciplinary sciences and incorporated with different fields of environment and information science.

- Environmental Informatics is an applied science field and also responsible for the different solutions in the environment and ecology.

- Environmental Informatics is about technological and manual documentation and procedure in environmental management.

- Contents, information systems are prime for health Environmental Information systems designing and development.

- Environmental Informatics is broader than Geo-Informatics or closely allied Environmental Information Management [4], [7], [13].

Environmental Informatics is the solution for different environmental allied subjects viz. Geology, Agriculture, Forestry, Geography, Climatology, Oceanography, Anthropology, Disaster Management, etc. There are following stakeholders of Environmental Informatics-

\section{Content and Information-}

Content and information are an important concern of Environmental Informatics as without content designing of Environmental Information Systems, Monitoring Systems become useless or not possible [19], [24].

\section{People-}

People are important stakeholders in Environmental Informatics and in this context, people mean the professional who design and develop Environmental Informatics systems and users of the systems [6], [9], [19].

\section{Environmental Affairs and Facets-}

Nature including aspects, objects and systems of Geology, Agriculture, Forestry, Geography, Climatology, Oceanography, Anthropology, Disaster Management and its stakeholders are the important aspects of Environmental Informatics 


\section{Technologies -}

Environmental Informatics consists of both Environment and Informatics and thus within Informatics following are important components (sub-technologies of IT) -

- Web Technologies

- Database Technologies

- Network Technologies

- Software Technologies

- Multimedia Technologies, etc

The stakeholders in Environmental Informatics is increasing rapidly and growing. The advantages are noticeable in different context [18], [22], [23].

\section{Environmental Informatics: Possible Positions and Educational Programs}

Environmental Informatics educated and similarly skilled professionals can get a different kind of job opportunities viz. as remote sensing specialists, ICT enable area foresters, ICT based refuge managers, environmental ICT consultants, wildlife information specialists and also in Natural resource agencies. The figure: 1 shows few possible jobs in Environmental Informatics [8], [10], [26].

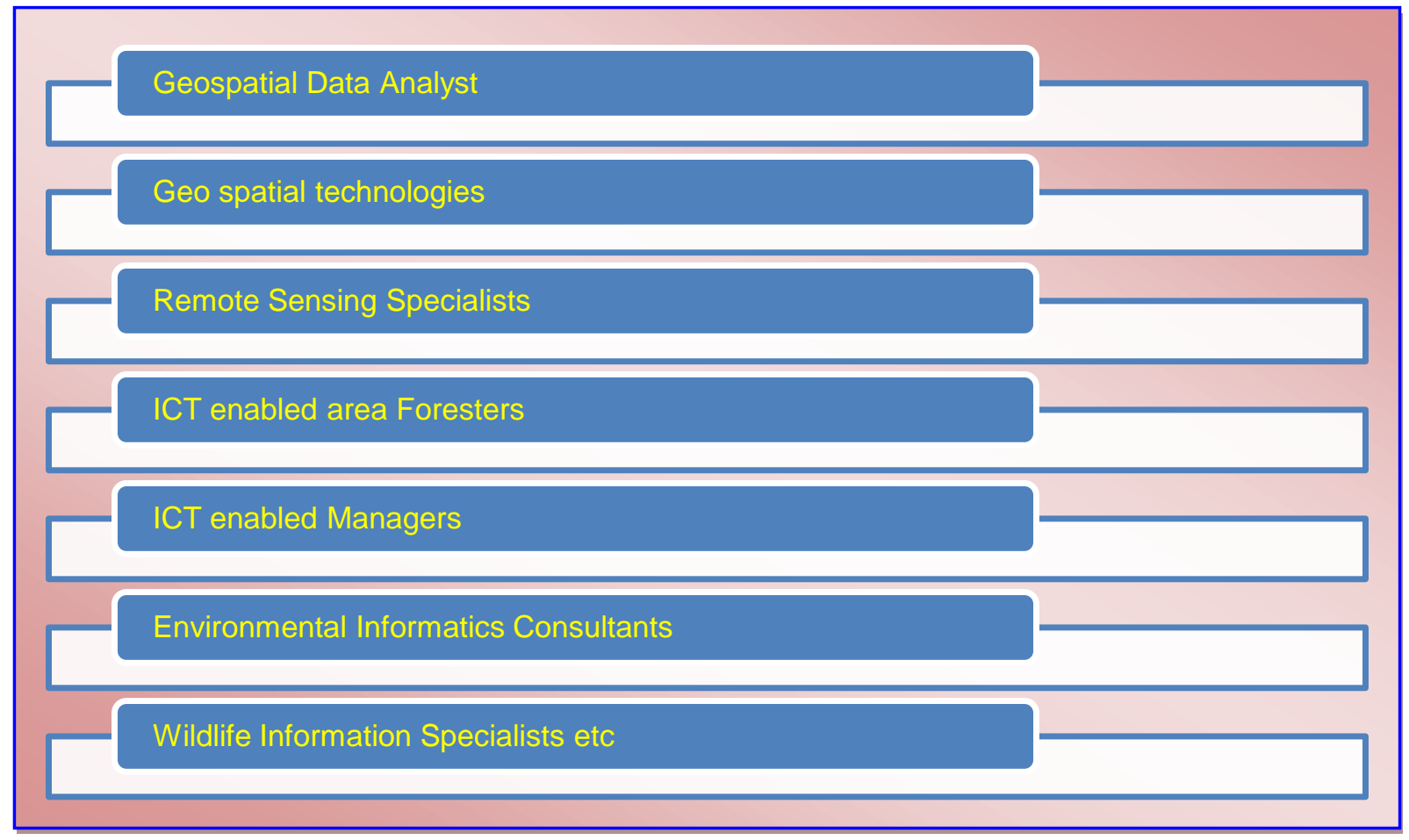

Fig:1 Few common job positions for Environmental Informatics Educated/ Skilled

The jobs and opportunities can vary in Environmental Informatics from country to country. As far as the University of Michigan's (it offers degrees in the field: https://seas.umich.edu) official website is concerned some of the featured companies in US/ Internationals are include as follows-

- Ducks Unlimited

- ENVIRON 
- ESRI

- Michigan Tech Research Institute

- National Oceanic and Atmospheric Administration (NOAA)

- Quantum Spatial

- The Nature Conservancy (TNC)

- United States Bureau of Land Management

- United States Forest Service

- World Resources Institute

Environmental Informatics professional and their job responsibilities thus also vary from profession to professions, herewith few brief job descriptions-

Ecoinformatics - Environmental Informatics professionals are responsible for developing the ideas and ways to access as well as in integrating repositories and databases of environmental-related content and information to solve environmental problems to different stakeholders.

Environmental data scientist -Weather, climate, agricultural problems can be solved by using integrated data analytics products and services, data delivery systems, and allied tools.

Ecological forecasting specialists - They are responsible for data and information delivery to the needy using different technologies of Computing and IT [3], [14], [25].

Ecosystems services consultant - Plans and executes environmental monitoring efforts through the design, evaluation, and installation of monitoring stations such as electronic data loggers, remote samplers, and remote communications systems.

Environmental modeler - Environmental Informatics is responsible for Integrating modeling, geo data analysis using IT components.

Geospatial technician - They utilize data in different settings and dedicated to building, maintaining, and accessing geographic information system databases [7], [15], [16].

Sustainability system analyst - They are responsible for system designing and development for the implementing policies and procedures for environmental management.

Hence, environmental informatics educated may enter in the job market and maybe the organizations related to the Agriculture, Space, Weather and Climatology, Environmental Protection Agency, Geological Survey, Central and State Agencies and Ministries, Departments and Organizations offers Forest Management and allied solutions, Marine Technologies, Disaster Management company and organizations, Environmental consulting firms, nonprofit organizations work on environment and ecologies, etc [10], [17], [20]. Due to this wide range of existing and future job potentialities many universities have started educational programs and as per the revealed few programs and universities listed in Table: 1. 
Table: 1Few universities offering Environmental Informatics programs

\begin{tabular}{|c|c|}
\hline Universities & Degree \\
\hline Auburn University, Alabama, US & BS Geo-Spatial Environmental Informatics \\
\hline Wuhan University, China & BSc Geo-Environmental Informatics \\
\hline Northern Arizona University, United States & BS Informatics (Environmental Informatics) \\
\hline $\begin{array}{l}\text { Georg August University of Göttingen, } \\
\text { Germany }\end{array}$ & BSc-CS and MSc-Environmental Informatics Integrated \\
\hline $\begin{array}{l}\text { University of North Carolina at Chapel Hill, } \\
\text { US }\end{array}$ & $\begin{array}{l}\text { BS-Environmental Science \& MS-Information Science } \\
\text { Dual Degree } \\
\text { Offered jointly by College of Environment, Ecology and } \\
\text { Energy with School of Information and Library Science }\end{array}$ \\
\hline $\begin{array}{l}\text { Virginia Polytechnic Institute and State } \\
\text { University, US }\end{array}$ & BS Environmental Informatics \\
\hline $\begin{array}{l}\text { The University of Applied Sciences, } \\
\text { Germany }\end{array}$ & $\begin{array}{l}\text { BSc Environmental Informatics and Business Information } \\
\text { Systems (Dual Degree) }\end{array}$ \\
\hline
\end{tabular}

Environmental Informatics programs are available in a wide range of titles viz. MS/ MSc with full concentration in Environmental Informatics, MS/MSc as specialization in Environmental Informatics in allied programs of Environment and also in IT/Computing. Even Post Graduate Diploma and Post Graduate Certificate also started by the universities. Most of these programs are the On-Campus only but come with facilities of Full Time and Part Time candidacy. Refer Table: 2 to learn a detailed university offers PG programs as per the result of the study/ method adopted.

Table: 2 Few universities offering Post Graduate level of Environmental Informatics programs

\begin{tabular}{|l|l|}
\hline \multicolumn{1}{|c|}{ Universities } & \multicolumn{1}{c|}{ Degree } \\
\hline University of Leicester, UK & $\begin{array}{l}\text { MSc (Environmental Informatics) } \\
\text { Regular On-Campus Only } \\
\text { Full Time/ Part-Time } \\
1 \text { Year to 2 Year } \\
180 \text { Credit }\end{array}$ \\
\hline University of Leicester, UK & $\begin{array}{l}\text { Post Graduate Diploma in Environmental Informatics } \\
\text { Regular On-Campus Only }\end{array}$ \\
\hline $\begin{array}{l}\text { Joma Kenyatta University of Agriculture and } \\
\text { Technology, Kenya }\end{array}$ & $\begin{array}{l}\text { MSc Environmental Information Systems } \\
\text { Full Time/ Part-Time }\end{array}$ \\
\hline $\begin{array}{l}\text { Georg August University of Göttingen, Germany } \\
\text { University of Leicester, UK }\end{array}$ & $\begin{array}{l}\text { MSc-PhD Environmental Informatics Integrated } \\
\text { Regular On-Campus Only } \\
\text { Full Time/ Part-Time }\end{array}$ \\
\hline
\end{tabular}




\begin{tabular}{|l|l|}
\hline University of Michigan, US & $\begin{array}{l}\text { MS Environment \& Ecology (Environmental } \\
\text { Informatics)_ } \\
\text { Geo-Spatial Data Science }\end{array}$ \\
\hline $\begin{array}{l}\text { University of Kassel } \\
\text { Germany }\end{array}$ & MSc Environmental Informatics \\
\hline Tennessee Tech University & Masters in Environmental Informatics (Professional) \\
\hline
\end{tabular}

It is worthy to note that most of these Masters are MSc only, while there are potentialities in MTech/ME degrees as well, and such possible programs are depicted in the next section.

\section{Environmental Informatics: Program Contents}

Environmental Informatics programs are interdisciplinary, so that it combines with various aspects of Informatics/ IT viz.

- Content and Information Management

- Database Technologies

- Network and Communication Technology

- Multimedia Technology

- Software Technology etc.

However, as far as Environment and allied areas are concerned, possible knowledge gradients in Environmental Informatics include the basics of as follows-

- Geology

- Agriculture

- Forestry

- Geography

- Climatology

- Oceanography, etc

It is further and detailed possible to study from the table: 3in which different Environmental Informatics related Masters programs are listed with courses.

Table: 3 Curriculum sample of few universities offering Masters in Environmental Informatics programs

\begin{tabular}{|l|l|l|}
\hline \multicolumn{1}{|c|}{ Universities } & \multicolumn{1}{|c|}{ Degree } & \multicolumn{1}{c|}{ Papers/ Courses } \\
& & $\begin{array}{l}\text { Core Modules (All) Sem: 1 (20 Cr) } \\
\text { Induction } \\
\text { Dissertation Tutorial } \\
\text { Introduction to GIS } \\
\text { Core Papers (any two) (60 Cr) } \\
\text { Earth Observation and Remote Sensing } \\
\text { Programming in R } \\
\text { Sustainable Management of Biological } \\
\text { resources: Ecosystem and Biodiversity } \\
\text { Conservation } \\
\text { Environmental economics }\end{array}$ \\
\hline $\begin{array}{l}\text { University of Leicester, } \\
\text { UK }\end{array}$ & Full Time/ Part-Time & \\
\hline
\end{tabular}




\begin{tabular}{|c|c|c|}
\hline & $\begin{array}{l}1 \text { Year to } 2 \text { Year } \\
180 \text { Credit }\end{array}$ & $\begin{array}{l}\text { Core Modules (All) Sem: } 2 \text { (60 Cr) } \\
\text { Geographic Visualization } \\
\text { GIS Research Methods in the field } \\
\text { Core Papers (any two) } \\
\text { Living with Environmental Changes } \\
\text { Ecological \& Environmental Assessment } \\
\text { Dissertation (60Cr) }\end{array}$ \\
\hline $\begin{array}{l}\text { University of Michigan, } \\
\text { US }\end{array}$ & $\begin{array}{l}\text { MS Environment \& Ecology } \\
\text { (Environmental Informatics)- } \\
\text { Geo-Spatial Data Science }\end{array}$ & 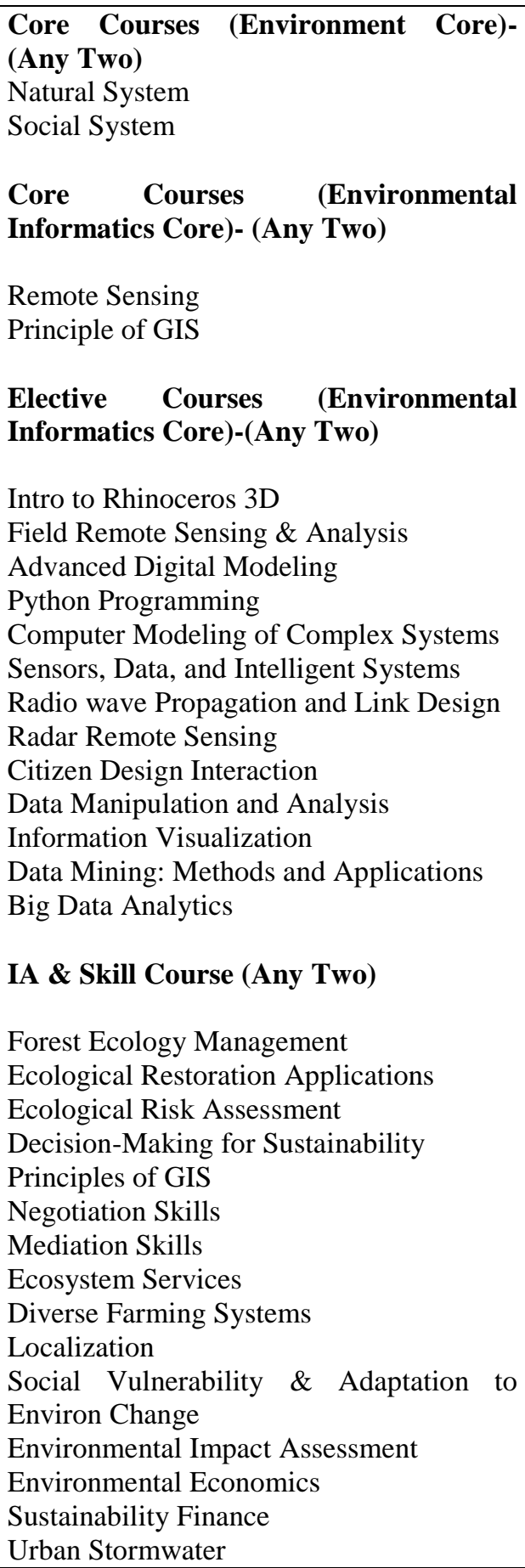 \\
\hline
\end{tabular}




\begin{tabular}{|c|c|c|}
\hline & & $\begin{array}{l}\text { Environmental Systems Analysis } \\
\text { Climate Adaptation Seminar } \\
\text { Landscape Planning }\end{array}$ \\
\hline $\begin{array}{l}\text { University of Kassel } \\
\text { Germany }\end{array}$ & MSc Environmental Informatics & $\begin{array}{l}\text { Semester } 1 \text { ( } 33 \text { Credit) } \\
\text { Critical elements of climate science and } \\
\text { climate policy } \\
\text { Parallel Algorithms and Programming } \\
\text { Systems } \\
\text { Ingenieur als Führungskraft } \\
\text { Methods for spatial data analysis } \\
\text { Machine Learning } \\
\text { Pattern Recognition } \\
\text { Semester } 1 \text { (27 Credit) } \\
\text { Introduction to environmental modeling } \\
\text { Presentation and Moderation } \\
\text { Integrated systems analysis: the water } \\
\text { cycle } \\
\text { Project } \\
\text { Seminar } \\
\text { Semester } 3 \text { (30 Credit) } \\
\text { Master's Thesis }\end{array}$ \\
\hline Tennessee Tech University & $\begin{array}{l}\text { Masters in Environmental } \\
\text { Informatics (Professional) }\end{array}$ & $\begin{array}{l}\text { Background Courses } \\
\text { Theory of GIS I } \\
\text { Theory of GIS II } \\
\text { Informatics (Professional } \\
\text { Management Core Compulsory } \mathbf{( 1 2} \\
\text { Credit) } \\
\text { Accounting Information for Management } \\
\text { Decisions } \\
\text { Organizational Leadership } \\
\text { Applied Linear Statistical Method } \\
\text { Strategic Marketing } \\
\text { Concentration Courses (18 Credit) } \\
\text { Programming GIS } \\
\text { Environmental Social Policy } \\
\text { Remote Sensing } \\
\text { Environmental Applications of GIS } \\
\text { Environmental Statistics } \\
\text { Internship } \\
\text { Electives (Any One) } \\
\text { Agriculture and Biological Statistics } \\
\text { Data Mining } \\
\text { Web-based Database Systems } \\
\text { Data Resource Management } \\
\text { Environmental Economics } \\
\text { Environmental Management Systems } \\
\text { GIS Project Development and }\end{array}$ \\
\hline
\end{tabular}




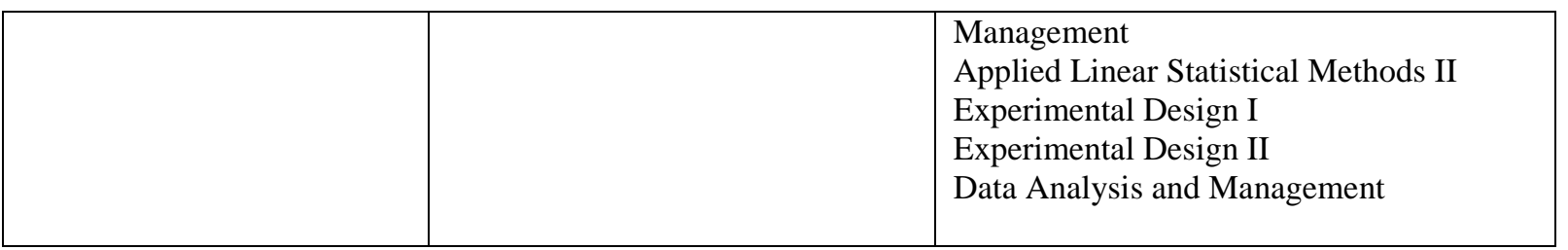

Hence it is noticed that within the Environmental Informatics different areas are booming viz. Agricultural Informatics, Geo-Informatics, Ecology Informatics, Forestry Informatics, etc. Moreover, apart from the independent topics and areas, few are merged and interdisciplinary viz.-

- Environmental Applications of GIS

- Introduction to environmental modeling

- Sustainable Management of Biological resources: Ecosystem and Biodiversity Conservation

- Environmental Social Policy et

\section{Possible Masters Program in Indian Context}

India is a developing nation and growing its economy as a knowledge economy. Further, it is to be noted that, India holds a higher number of higher educational institutes comprise of 900+ Universities, 40000+ Colleges, 100+ INI, etc. In many universities, Environmental Science and allied nomenclatures are offered and it is possible to offer academic programs on these subjects as specializations in Environmental Informatics. Table: 4 depicted possible programs in this regard.

Table: 4 Possible Environmental Informatics specialization programs in Indian context at Environmental Science and allied subjects

\begin{tabular}{|c|c|c|}
\hline Stream/ Subjects & Nomenclature/ Degree & Applications \\
\hline Environmental Science & $\begin{array}{l}\text { MSc/MS/MTech-Environmental } \\
\text { Science (Environmental Informatics) }\end{array}$ & $\begin{array}{l}\text { Utilizations of Environmental } \\
\text { Informatics tools and techniques } \\
\text { in different areas of Environment } \\
\text { and Ecology }\end{array}$ \\
\hline Environmental Engineering & $\begin{array}{l}\text { MSc/MS/MTech-Environmental } \\
\text { Science (Environmental Informatics) }\end{array}$ & $\begin{array}{l}\text { Utilizations of Environmental } \\
\text { Informatics tools and techniques } \\
\text { in different areas of } \\
\text { Environmental Technological } \\
\text { Solution and Engineering } \\
\end{array}$ \\
\hline EnvironmentalManagement & $\begin{array}{l}\text { MSc/MS/MTech-Environmental } \\
\text { Science (Environmental Informatics) }\end{array}$ & $\begin{array}{l}\text { Utilizations of Environmental } \\
\text { Informatics tools and techniques } \\
\text { in different areas of } \\
\text { Environmental Technological } \\
\text { Solution and Engineering }\end{array}$ \\
\hline Geography & $\begin{array}{l}\text { MSc/MS/MTech-Geography } \\
\text { (Environmental Informatics) }\end{array}$ & $\begin{array}{l}\text { Utilizations of Environmental } \\
\text { Informatics tools and techniques } \\
\text { in Geography and related }\end{array}$ \\
\hline Agriculture & $\begin{array}{l}\text { MSc/MS/MTech-Agriculture } \\
\text { Agricultural } \quad \text { Technology } \\
\text { (Environmental Informatics) }\end{array}$ & $\begin{array}{l}\text { Utilizations of Environmental } \\
\text { Informatics tools and techniques } \\
\text { in Agricultural activities }\end{array}$ \\
\hline Earth Science & $\begin{array}{l}\text { MSc/MS/MTech-Earth Science } \\
\text { (Environmental Informatics) }\end{array}$ & $\begin{array}{l}\text { Utilizations of Environmental } \\
\text { Informatics } \\
\text { technologies in different areas of } \\
\text { Earth Sciences }\end{array}$ \\
\hline
\end{tabular}


IRA-International Journal of Management \& Social Sciences

\begin{tabular}{|l|l|l|}
\hline Geology & $\begin{array}{l}\text { MSc/MS/MTech-Geology } \\
\text { (Environmental Informatics) }\end{array}$ & $\begin{array}{l}\text { Utilizations of Environmental } \\
\text { Informatics tools and techniques } \\
\text { in Geological affairs }\end{array}$ \\
\hline Forestry & $\begin{array}{l}\text { MSc/MS/MTech-Forestry } \\
\text { (Environmental Informatics) }\end{array}$ & $\begin{array}{l}\text { Utilizations of Environmental } \\
\text { Informatics tools and techniques } \\
\text { in Forestry, Forest Management, } \\
\text { Planning, etc }\end{array}$ \\
\hline
\end{tabular}

Further, as there are numerous subjects within Environmental Science viz. Geology, Agriculture, Forestry, Geography, Climatology, Oceanography, and in all these programs Environmental Informatics specialization can be incorporated suitably.

\section{Possible Masters Program in Research Context: Indian Context}

Environmental Informatics an interdisciplinary program needs skill sets of different areas, further professionals from allied subjects of the environment and informatics can be interested to join in the field as a research concentration. Hence there may be possible programs with research concentration with following degrees (also refer Table: 5) -

- MSc by Research

- MS by Research

- MTech/ME by Research

Table: 5 Possible Environmental Informatics specialization programs in the Indian context in research concentration

\begin{tabular}{|c|c|c|}
\hline \multicolumn{3}{|c|}{ Possible Allied Environmental Science Core UPG by Research Degrees in India } \\
\hline Stream/ Subjects & Nomenclature/ Degree & Remarks \\
\hline Environmental Science & $\begin{array}{l}\text { MSc/MS/MTech by Research - } \\
\text { Environmental } \\
\text { (Environmental Informatics) }\end{array}$ & $\begin{array}{l}\text { Suitable for the future } \\
\text { academicians and researchers, } \\
\text { scientist interested in } \\
\text { Environmental Informatics tools } \\
\text { and techniques in Environmental } \\
\text { areas }\end{array}$ \\
\hline Ecology & $\begin{array}{l}\text { MSc/MS/MTech by Research - } \\
\text { Ecology } \\
\text { Informatics) }\end{array}$ & $\begin{array}{l}\text { Suitable for the future } \\
\text { academicians and researchers, a } \\
\text { scientist interested in } \\
\text { Environmental Informatics tools } \\
\text { and techniques in Ecology }\end{array}$ \\
\hline Environmental Studies & $\begin{array}{l}\text { MSc/MS/MTech by Research - } \\
\text { Environmental } \\
\text { (Environmental Informatics) }\end{array}$ & $\begin{array}{l}\text { Suitable for the future } \\
\text { academicians and researchers, } \\
\text { scientist interested in } \\
\text { Environmental Informatics tools } \\
\text { and techniques in Environmental } \\
\text { and Social Issues }\end{array}$ \\
\hline Environmental Engineering & $\begin{array}{l}\text { BTech/MSc/MS/MTech by Research } \\
\text {-Environmental Engineering } \\
\text { (Environmental Informatics) }\end{array}$ & $\begin{array}{l}\text { Suitable for the future } \\
\text { academicians and researchers, } \\
\text { scientist interested in } \\
\text { Environmental Informatics tools } \\
\text { and techniques in Environmental } \\
\text { areas }\end{array}$ \\
\hline
\end{tabular}


IRA-International Journal of Management \& Social Sciences

\begin{tabular}{|c|c|c|}
\hline Environmental Management & $\begin{array}{lr}\text { MSc/MS/MTech/ } & \text { BCom/ BBA by } \\
\text { Research } & \text {-Environmental } \\
\text { Management } & \text { (Environmental } \\
\text { Informatics) } & \end{array}$ & $\begin{array}{l}\text { Suitable for the future } \\
\text { academicians and researchers, } \\
\text { scientist interested in } \\
\text { Environmental Informatics tools } \\
\text { and techniques work in } \\
\text { Environmental Management }\end{array}$ \\
\hline Environmental Statistics & $\begin{array}{l}\text { MSc/MS/MTech by Research - } \\
\text { Environmental } \\
\text { (Environmental Informatics) }\end{array}$ & $\begin{array}{l}\text { Suitable for the future } \\
\text { academicians and researchers, } \\
\text { scientist interested in } \\
\text { Environmental Informatics tools } \\
\text { and techniques in Environmental } \\
\text { Statistics and Mathematics }\end{array}$ \\
\hline Wildlife Sciences & $\begin{array}{l}\text { MSc/MS/MTech by Research - } \\
\text { Wildlife Science (Environmental } \\
\text { Informatics) }\end{array}$ & $\begin{array}{l}\text { Suitable for the future } \\
\text { academicians and researchers, } \\
\text { scientist interested in } \\
\text { Environmental Informatics tools } \\
\text { and techniques in Wildlife } \\
\text { Sciences }\end{array}$ \\
\hline Geography & $\begin{array}{lrr}\text { MSc/MS/MTech by Research - } \\
\text { Geography } & \text { (Environmental } \\
\text { Informatics) } & \end{array}$ & $\begin{array}{l}\text { Suitable for the future } \\
\text { academicians and researchers, } \\
\text { scientist interested in } \\
\text { Environmental Informatics tools } \\
\text { and techniques in different areas } \\
\text { of Geography }\end{array}$ \\
\hline Agriculture & $\begin{array}{lrr}\text { MSc/MS/MTech by Research - } \\
\text { Agriculture } & \text { (Environmental } \\
\text { Informatics) } & \end{array}$ & $\begin{array}{l}\text { Suitable for the future } \\
\text { academicians and researchers, } \\
\text { scientist interested in } \\
\text { Environmental Informatics tools } \\
\text { and techniques in Agriculture }\end{array}$ \\
\hline Earth Science & $\begin{array}{l}\text { MSc/MS/MTech by Research -Earth } \\
\text { Science (Environmental Informatics) }\end{array}$ & $\begin{array}{l}\text { Suitable for the future } \\
\text { academicians and researchers, } \\
\text { scientist interested in } \\
\text { Environmental Informatics tools } \\
\text { and techniques in Earth Sciences }\end{array}$ \\
\hline
\end{tabular}

\section{Suggestion}

- Environmental Informatics as a field is growing internationally and thus in India as well the field can be started at a Master's level with coursework or research.

- The programs can be started at Masters directly with full-fledged manner viz. MSc/MTech, etc on Environmental Informatics.

- Further if possible, subfield specializations may be offered viz. MSc Environmental Informatics (GeoInformatics), MSc Environmental Informatics (Forest Informatics), etc as a super specialty.

- There are lots of programs in the Environmental Sciences sub-areas viz. Geology, Agriculture, Forestry, Geography, Climatology, Oceanography, and in such areas Environmental Informatics or allied fields can be offered. 
- Proper adjustment, procedure, and collaboration with the allied departments (viz. Informatics/ IT departments with Environment related) can be taken to start the programs on Environmental Informatics.

\section{Conclusion}

Environmental Informatics is growing internationally due to its wide range of applications not only in core areas of the environment but also in allied areas viz. Geology, Agriculture, Forestry, Geography, Climatology, Oceanography, Anthropology, etc. In India, though Informatics or Information Science departments/ or academic units are limited but can be offered from the initiative of Information Technology, Computer Science or allied departments with the Environmental Sciences or allied departments viz. Environmental Science, Environmental Engineering, Environmental Management, etc. In this context, initiatives from the respective departments from the universities or by the MHRD or by the state government are required. Further Government departments, Ministries, and Organizational initiatives required from the allied branches viz. Agriculture, Forestry, Environment, Disaster Management, etc. Further, if Masters programs are difficult to start initially then the short-term programs, workshops, events can be started for proper development of the field and complete sustainability.

\section{References}

[1] Allen T. F. Giampietro M. \& Little A. M. (2003). Distinguishing ecological engineering from environmental engineering. Ecological Engineering20(5) 389-407.

[2] Dayal, I. (2002). Developing management education in India. Journal of Management Research, 2(2), 98.

[3] Goldberg-Kahn, B., \& Healy, J. C. (1997). Medical informatics training in pathology residency programs. American journal of clinical pathology, 107(1), 122-127.

[4] Gupta, D., \& Gupta, N. (2012). Higher education in India: structure, statistics and challenges. Journal of Education and Practice, 3(2). 17-24.

[5] Henricks, W. H., Boyer, P. J., Harrison, J. H., Tuthill, J. M., \& Healy, J. C. (2003). Informatics training in pathology residency programs: proposed learning objectives and skillsets for the new millennium. Archives of pathology \& laboratory medicine, 127(8), 1009-1018.

[6] Kapur, D., \& Mehta, P. B. (2004). Indian higher education reform: From half-baked socialism to half-baked capitalism. Center for international development working paper, 103.

[7] Nambissan, G. B., \& Rao, S. (Eds.). (2013). Sociology of education in India: Changing contours and emerging concerns. New Delhi: Oxford University Press.

[8] Nikolov, R. (1987). Integrating informatics into the curriculum. Education and Computing, 3(3), 269-74.

[9] Paul, Prantosh Kumar, Poovammal E (2013).Information Service Vis-a-Vis Online and Cloud Environment in $21^{\text {st }}$ Century: Promoting Environmental \& Bio Informatics. Journal of Chemical and Pharmaceutical Sciences, 9 (4), 3164-3168.

[10] Paul, Prantosh Kumar (2013). Business Informatics: Emerging Domain of Interdisciplinary Information Science with Possibilities in I-Schools. International Journal of Marketing Theory, 3 (2), 113-120.

[11] Paul, Prantosh Kumar (2013). MSc-Information Science [Geo Informatics]: Overview emphasizing two proposed curriculum for sophisticated GeoSpatial development.International Journal of Pharmaceutical and Biological Research (IJPBR), 4 (5), 218-227.

[12] Paul, Prantosh Kumar, Dipak Chaterjee (2013).Retail Informatics: The Wonderful Cluster of Information Science and Marketing Management. SIT Journal of Management, 3 (11), 89-95

[13] Paul, Prantosh Kumar, Jhuma Ganguly, M Ghosh (2013). Chemical Information Management powered by Chemo-Informatics: Possibilities and opportunities emphasizing need and way in Academics and Universities. Current Trends in Biotechnology and Chemical Research, 3 (2), 137-141. 
[14] Paul, Prantosh Kumar, A. Bhuimali, Dipak Chaterjee (2016).Retail Informatics: Basics and Emerging Scenario with Special Reference to Design and Development of Proposed MSc-Information Science (Retail Informatics) in Indian Scenario. International Journal of Information Dissemination \& Technology,140-144.

[15] Paul, P.K., and Aithal, P.S. (2017).Bio Informatics in private universities in India: An Emerging Study on promotion of Biological Information Sciences in Higher Education in Proceedings of National Conference on Innovations and implications in Information Technology, Management, Social Sciences and Education, 84-92.

[16] Paul, P.K. and Aithal, P.S. (2017) Bio Informatics in Private Universities in India: An Emerging Study on Promotion of Biological Information Sciences. International Journal of Bioinformatics and Biological Sciences, $5(1), 1-7$.

[17] Paul, P.K. Aithal, P.S.(2017) Informatics as a Branch in Indian Academics with Case of Private Universities: Emphasizing Biological Information Sciences. Current Trends in Biotechnology and Chemical Research, 7(12), 37-42.

[18] Paul, P. K., Aithal, P. S., \& Bhuimali, A. (2017). Business Informatics: A possible specialization of MScInformation Science \& Technology (IST): Challenges and Opportunities in Developing Countries Context.International Journal of Recent Researches in Science, Engineering \& Technology, 5 (10), 54-63.

[19] Paul, P.K., Bhuimali, A., Aithal, P. S. \& Dangwal, K.L. (2017). Quantum Information Science-The Domain of Future Informatics Practice: Emphasizing Possibilities, Challenges and Academic Scenario. International Journal of Scientific Research in Physics and Applied Sciences, 5(5), 22-26.

[20] Paul, P.K. Bhuimali, A. and Aithal, P. S., (2017). Indian Higher Education: With Slant to Information Technology - a Fundamental Overview. International Journal on Recent Researches In Science, Engineering \& Technology, 5(11), 31-50.

[21] Paul, P.K., Aithal, P. S. \& Bhuimali, A. (2018). Business Informatics: With Special Reference to Big Data as an emerging Area: A Basic Review.International Journal of Recent Researches in Science, Engineering \& Technology, 6 (04), 21-27.

[22] Sood, R., \& Adkoli, B. V. (2000). Medical education in India-problems and prospects. J Indian Acad Clin Med, 1(3), 210-212.

[23] Sohani, N., \& Sohani, N. (2012). Developing interpretive structural model for quality framework in higher education: Indian context. Journal of Engineering, Science \& Management Education, 5(2), 495-501.

[24] Supe, A., \& Burdick, W. P. (2006). Challenges and issues in medical education in India. Academic Medicine, 81(12), 1076-1080.

[25] Tayade, M. C., \& Kulkarni, N. B. (2011). The Interface of technology and medical education in India: current trends and scope. Indian Journal of Basic \& Applied Medical Research, 1(1), 8-12.

[26] Tilak, J. B. (2008). Transition from higher education as a public good to higher education as a private good: The saga of Indian experience. Journal of Asian Public Policy, 1(2), 220-234. 